\title{
Efficacy and Safety of Tregopil, a Novel, Ultra-Rapid Acting Oral Prandial Insulin Analog, as Part of a Basal-Bolus Regimen in Type 2 Diabetes: A Randomized, Active Controlled Phase 3 Study
}

Running title: Tregopil for PPG control in type 2 diabetes

Harold E Lebovitz $\mathrm{MD}^{1}$, Alexander Fleming $\mathrm{MD}^{2}$, Alan D Cherrington $\mathrm{MD}^{3}$, Shashank Joshi $\mathrm{MD}^{4}$, Sandeep N. Athalye MD ${ }^{5}$, Subramanian Loganathan $\mathrm{MD}^{5}$, Ashwini Vishweswaramurthy $\mathrm{MD}^{5}$, Jayanti Panda M.Pharm ${ }^{5}$, Ashwani Marwah M.Sc ${ }^{5}$

\author{
Affiliations: \\ ${ }^{1}$ State University of New York Health Science Center at Brooklyn, Brooklyn, New York, USA \\ ${ }^{2}$ Kinexum, Harpers Ferry, West Virginia, USA \\ ${ }^{3}$ Vanderbilt University School of Medicine-Basic Sciences, Nashville, Tennessee, USA \\ ${ }^{4}$ Consultant, Joshi Clinic and Lilavati Hospital, Mumbai, Maharashtra, India \\ ${ }^{5}$ Affiliated to Biocon Biologics Ltd., Bengaluru, Karnataka, India, at the time of preparation of \\ this manuscript
}

\section{*Corresponding author:}

\section{Dr Subramanian Loganathan,}

Biocon Biologics Limited,

Biocon House, Semicon Park,

Electronic City Phase 2,

Bangalore (Karnataka),

560010

India

Email ID: subramanian.1101@biocon.com 
medRxiv preprint doi: https://doi.org/10.1101/2022.02.15.22270708; this version posted February 15, 2022. The copyright holder for this preprint (which was not certified by peer review) is the author/funder, who has granted medRxiv a license to display the preprint in

All rights reserved. No reuse allowed without permission.

\begin{abstract}
OBJECTIVE

Efficacy and safety of ultra-rapid acting oral prandial insulin Tregopil (Tregopil) was compared with insulin aspart (IAsp) in patients with type-2 diabetes on stable doses of insulin glargine and metformin.
\end{abstract}

\title{
RESEARCH DESIGN AND METHODS
}

In this open-label, active-controlled trial, patients with type- 2 diabetes, with $\mathrm{HbA}_{1 \mathrm{c}} \geq 7 \%$ and $\leq 9 \%$ and 2 -h postprandial glucose $(\mathrm{PPG}) \geq 180 \mathrm{mg} / \mathrm{dL}$ were randomized (1:1:1) to Tregopil (30 $\mathrm{mg}[n=30], 45 \mathrm{mg}[n=31])$ and IAsp ( $n=30$; dose titrated based on self-monitored blood glucose [SMBG]). Postprandial plasma glucose excursion (PPGE) and PPG were assessed from the standardized test meal (STM) and 9- point SMBG. The primary outcome measure was change from baseline (CFB) in $\mathrm{HbA}_{1 \mathrm{c}}$ at week 24.

\section{RESULTS}

The Tregopil (30 mg) arm showed significantly lesser 1-h PPGE (CFB) excursion after the STM versus IAsp (Estimated Treatment Difference [ETD], 95\% CI, -45.33 mg/dL [-71.91, -8.75], $P=0.001$ ) and 1-h PPG trended towards a better control. The combined Tregopil group (30+45 mg) showed lower PPGE at 15 mins as compared to IAsp. Meal-wise analysis showed lower 1-h PPGE and PPG in the Tregopil groups post-breakfast. Clinically significant hypoglycemia was lower with Tregopil groups versus IAsp (rate ratio: 0.69).

\section{CONCLUSIONS}

Tregopil demonstrated an ultra-fast onset and short-duration prandial insulin profile with good safety. Tregopil improved the 1-h PPG and overall PPG control compared to IAsp. A further reduction in $\mathrm{HbA}_{1 c}$ compared to baseline was not observed, likely as a result of variability in the control of fasting glucose level over the duration of the study. 
medRxiv preprint doi: https://doi.org/10.1101/2022.02.15.22270708; this version posted February 15, 2022. The copyright holder for this preprint (which was not certified by peer review) is the author/funder, who has granted medRxiv a license to display the preprint in

All rights reserved. No reuse allowed without permission.

\section{INTRODUCTION}

Patients with type 2 diabetes who fail to achieve glycemic targets despite oral antidiabetic drugs (OADs) and lifestyle modifications require insulin therapy (1) and subcutaneous (SC) injection is the most commonly used route of administration (2). However, the SC injection is associated with challenges like needle phobia, injection site pain, lipodystrophy and may lead to patient noncompliance. Further, the occurrence of peripheral hyperinsulinemia (3), may result in adverse effects such as weight gain and hypoglycemia (4). Oral delivery of insulin has been long sought after. Insulin delivered orally is absorbed directly into the portal circulation, and resembles the pancreatic secretion of insulin and its portal transport, resulting in a higher hepatic insulin exposure (5). Hepatic delivery of oral insulin is associated with reduced risk of hypoglycemia (6), stabilized body weight (5), improved therapeutic compliance, and hence a better quality of life (7).

In patients with type 2 diabetes, postprandial glucose (PPG) levels typically peak about 2-h after a meal (8). Elevation in PPG is due to loss of first-phase insulin secretion, reduced insulin sensitivity in peripheral tissues, and decreased suppression of hepatic glucose output after meals (9). Bolus premeal insulin treatment reduces PPG excursion (PPGE) in patients with type 2 diabetes (10). Compared to the regular human insulin, first-generation, rapid-acting insulin analogs have shown a better PPGE control. However, there remains an unmet need with insulin analogs for a faster onset and a shorter duration of action, which could potentially help to achieve a better PPG control than the rapid-acting insulin analogs $(11,12)$. Ultrafast-acting oral insulins can potentially simulate the first-phase insulin release after a meal and may lead to a better control of PPG and PPGE. Hence, ultrafast-acting oral insulins can help to correct the postprandial insulin deficiency in patients with type 2 diabetes (13). 
medRxiv preprint doi: https://doi.org/10.1101/2022.02.15.22270708; this version posted February 15, 2022. The copyright holder for this preprint (which was not certified by peer review) is the author/funder, who has granted medRxiv a license to display the preprint in

All rights reserved. No reuse allowed without permission.

Insulin Tregopil (hereafter referred to as Tregopil), is an ultrafast-onset, short-acting oral prandial insulin analog. It is a recombinant human insulin that contains a single, short-chain amphiphilic oligomer modified with the covalent attachment of methoxy-triethylene-glycolpropionyl moiety at Lys- $\beta 29$-amino group of the B chain via an amide linkage (14). Tregopil restores insulin availability during the immediate post-meal period with a median time-to-peak pharmacodynamic effect, i.e., best glucose reduction being $30-40$ min post-dose (14). It possibly mimics the release of insulin during the first-phase period and reduces early postprandial hyperglycemia (PPH) in patients with type 2 diabetes (14). Moreover, the efficacy of Tregopil on the initial PPG control has been well established in a sequential single ascending dose study versus placebo (14) and in a phase-3 randomized, placebo-controlled study in patients with type 2 diabetes on optimal doses of metformin (data on file). The current study evaluated the efficacy and safety of two doses of Tregopil (30 mg and $45 \mathrm{mg}$ ) compared to insulin Aspart (IAsp) in patients with type 2 diabetes being treated with stable doses of insulin glargine and metformin (+/- OADs).

\section{RESEARCH DESIGN AND METHODS}

\section{Study Setting and Population}

This study was a 24-week, open-label, randomized, parallel-group, phase 2/3 study (CTRI No.: CTRI/2017/11/010560; Clinicaltrials.gov identifier: NCT03430856) conducted across 20 centers in India between 2017 and 2019. Patients with an established diagnosis of type 2 diabetes (American Diabetes Association [ADA] 2017 guidelines; glycated hemoglobin $\left[\mathrm{HbA}_{1 \mathrm{c}}\right] \geq 6.5 \%$ ) (15) for at least 6 months before screening and with $\mathrm{HbA}_{1 \mathrm{c}}$ levels between $7.5 \%$ and $10 \%$ (58$86 \mathrm{mmol} / \mathrm{mol}$ ) at screening, and on a stable dose of metformin \pm OADs \pm basal insulin, and with $\mathrm{HbA}_{1 \mathrm{c}}$ levels between $7 \%$ and $9 \%(53-75 \mathrm{mmol} / \mathrm{mol})$ at randomization, and aged between 18 and 70 years were enrolled into the run-in period (detailed inclusion and exclusion criteria are 
medRxiv preprint doi: https://doi.org/10.1101/2022.02.15.22270708; this version posted February 15, 2022. The copyright holder for this preprint (which was not certified by peer review) is the author/funder, who has granted medRxiv a license to display the preprint in

All rights reserved. No reuse allowed without permission.

given in Supplementary Methods: A). All study participants provided written informed consent confirming their voluntary participation. The trial was approved by respective independent ethics committees/institutional review boards (details given in Supplementary Methods: B) and conducted in accordance with the Declaration of Helsinki, Indian Council of Medical Research Ethical guidelines for Biomedical Research, and Good Clinical Practices.

\section{Study Procedure}

The trial duration was approximately 37 weeks ( 3 weeks screening period, 8 weeks run-in period, 24 weeks treatment, and 2 weeks safety follow-up).

\section{Randomization}

At the end of the run-in period, patients meeting the randomization criteria (details specified in Supplementary Methods: C1) were randomized (1:1:1) to Tregopil (30 mg [ $n=30], 45 \mathrm{mg}$ $[n=31])$ and IAsp $(n=30)$ in addition to optimized doses of insulin glargine and metformin (+/- OADs) (Supplementary Fig. S1). The randomization scheme was produced using a validated system and an interactive voice response system was used to assign treatment at each site. While the treatment allotment was open label, post baseline $\mathrm{HbA}_{1 \mathrm{c}}$ assessments were blinded to the investigators throughout the treatment period.

\section{Dosing and Dose Titration}

Tregopil doses, $30 \mathrm{mg}$ ( 2 tablets of $15 \mathrm{mg}$ each) and $45 \mathrm{mg}$ ( 3 tablets of $15 \mathrm{mg}$ each), were administered orally thrice daily (TID), $10 \pm 2 \mathrm{~min}$ before each of the three major meals in a day. SC IAsp injection $(100 \mathrm{U} / \mathrm{mL})$ was administered TID, within 5 min before each of the three major meals. Additional details on dosing are provided in Supplementary Fig. S2. During the first 4 weeks of the treatment period (active titration period), study doses were up-/down-titrated by the investigator as per prespecified titration algorithms based on self-monitored blood glucose 
medRxiv preprint doi: https://doi.org/10.1101/2022.02.15.22270708; this version posted February 15, 2022. The copyright holder for this preprint (which was not certified by peer review) is the author/funder, who has granted medRxiv a license to display the preprint in

All rights reserved. No reuse allowed without permission.

(SMBG) levels and hypoglycemia criteria to achieve target PPG levels. The patients were instructed on the identified optimum dosage regimen and advised to follow it for the remainder of the treatment period. Additional information is provided in Supplementary Methods: C2.

\section{Study Endpoints}

PPG-related efficacy assessments included PPG parameters (PPG and PPGE) assessed following standardized test meal ([STM] administered at breakfast, at baseline [randomization visit], and weeks 12, 20, and 24), 9-point SMBG (performed at baseline and weeks 8, 12, 16, and 24) and formed important secondary endpoints of the study. Fasting plasma glucose (FPG) was also assessed.

The primary endpoint was change from baseline (CFB) in $\mathrm{HbA}_{1 \mathrm{c}}$ levels at week 24. Secondary endpoints included the number of severe or clinically significant hypoglycemic events during the treatment period, classified according to ADA 2017 and Food and Drug Administration guidelines (15). Treatment-emergent adverse events (TEAEs) were summarized based on the severity of adverse events (AEs) and relationship to trial medication (16).

\section{Post-hoc analyses to evaluate different groups}

Analyses were carried out to evaluate the relationship between patterns in plasma glucose response and $\mathrm{HbA}_{1 \mathrm{c}}$ as well as variations in PPG and $\mathrm{HbA1c}$. Estimated $\mathrm{HbA}_{1 c}\left(\mathrm{eA}_{1 \mathrm{c}}\right.$ ) was calculated using the formula: mean glucose $(\mathrm{mg} / \mathrm{dL}) * 0.0348+1.6(17)$ (details are provided in Supplementary Methods: C3). Additionally, based on 9-point SMBG levels at weeks 24 and 12, PPG parameters were analyzed using General Linear Mixed Models (PROC MIXED \& PROC MEANS) along with corresponding two-sided $P$-value, 95\% confidence interval (CI), and descriptive statistics. 
medRxiv preprint doi: https://doi.org/10.1101/2022.02.15.22270708; this version posted February 15, 2022. The copyright holder for this preprint (which was not certified by peer review) is the author/funder, who has granted medRxiv a license to display the preprint in

All rights reserved. No reuse allowed without permission.

\section{Safety}

Safety evaluation included assessment of AEs and serious AEs (SAEs), symptomatic hypoglycemia, SMBG, 3-point SMBG, vital signs, and standard clinical laboratory evaluations (additional information is provided in Supplementary Methods: C4).

\section{Statistical Analysis}

All randomized patients were included in the intent-to-treat analysis set (ITT), while the safety analysis set included randomized patients on at least one dose of the study drug. Per-protocol analysis set included all ITT patients who met all inclusion requirements, did not meet any exclusion criteria, had a baseline $\mathrm{HbA}_{1 \mathrm{c}}$ measurement, were exposed to the study medication, had at least one $\mathrm{HbA}_{1 \mathrm{c}}$ measurement at or after 8 weeks of randomization, and had no protocol deviation that affected the primary outcome. Patient follow-ups were carried out at study-specific timepoints for efficacy and safety assessments.

As this was a proof-of-concept exploratory study, no statistical rationale was defined for the sample size estimation. A minimum of 30 patients in each treatment group was deemed adequate to evaluate the study endpoints. Continuous variables were summarized using descriptive statistics as mean, median, standard deviation, and 95\% CI (minimum and maximum). Categorical variables were summarized as counts and percentages. All statistical hypothesis tests were performed at a $5 \%$ level of significance (two-sided test). $P$-values $<0.05$ were considered statistically significant. All statistical analyses were performed using SAS $^{\circledR}$ version 9.4 (or higher) for Windows (SAS Institute Inc., Cary, North Carolina, USA). 
medRxiv preprint doi: https://doi.org/10.1101/2022.02.15.22270708; this version posted February 15, 2022. The copyright holder for this preprint (which was not certified by peer review) is the author/funder, who has granted medRxiv a license to display the preprint in

All rights reserved. No reuse allowed without permission.

\section{RESULTS}

Overall, 91 patients were randomized to the Tregopil (30 $\mathrm{mg}[n=30], 45 \mathrm{mg}[n=31])$ and IAsp groups ( $n=30$ ), of which 85 patients completed the trial (Supplementary Fig. S1). Baseline and clinical characteristics were balanced between the treatment groups (Supplementary Table S1).

\section{Postprandial Glucose Control}

\section{Standardized Test Meal}

\section{$P P G$}

Baseline mean PPG values up to 1-h and up to 0-4 h post meal for all the treatment groups are shown in Fig. 1a and 1b, respectively and the mean data for the same at week 24 are given in Fig. 1c and 1d. Similarly, the mean and CFB of PPG levels from 1-h to 4-h at week 24 are summarized in Table 1 (the 1-h and 2-h estimated treatment differences [ETD] for PPG are provided in Supplementary Table S2). At week 24, the mean 1-h PPG levels were numerically lower and the corresponding CFB greater with Tregopil, indicating more effective control compared to IAsp (Table 1 and Fig. 1c), while the mean 2-h PPG and CFB levels were comparable (Table 1 and Fig. 1d), indicating control as effective as IAsp. The mean week 24 3- $\mathrm{h}$ and 4-h PPG were quantitatively lower and the corresponding CFB was greater in the IAsp group versus the Tregopil groups (Fig. 1d). A similar trend in the mean PPG and CFB levels was observed at week 12; however, no statistically significant differences in any of the parameters were observed between the treatment groups. Although glucose control in the IAsp group was numerically better in the later post meal period, i.e., at 3-h and 4-h, area under the curve (AUCs) for glucose over the 4-h post meal period of the Tregopil and IAsp groups were similar (Table 2). 
medRxiv preprint doi: https://doi.org/10.1101/2022.02.15.22270708; this version posted February 15, 2022. The copyright holder for this preprint (which was not certified by peer review) is the author/funder, who has granted medRxiv a license to display the preprint in All rights reserved. No reuse allowed without permission.

Tregopil groups had a higher proportion of patients meeting the more stringent 2-h PPG target level (<140 mg/dL) at week $24(30 \mathrm{mg}, 21.4 \% ; 45 \mathrm{mg}, 26.7 \%)$ compared to the IAsp group (17.2\%) (Supplementary Fig. S3). The overall PPG improvement occurred despite a slight worsening of FPG from baseline in the Tregopil groups vs similar levels maintained or slight improvement in FPG in the IAsp group.

a) Pre-treatment up to $1-h$

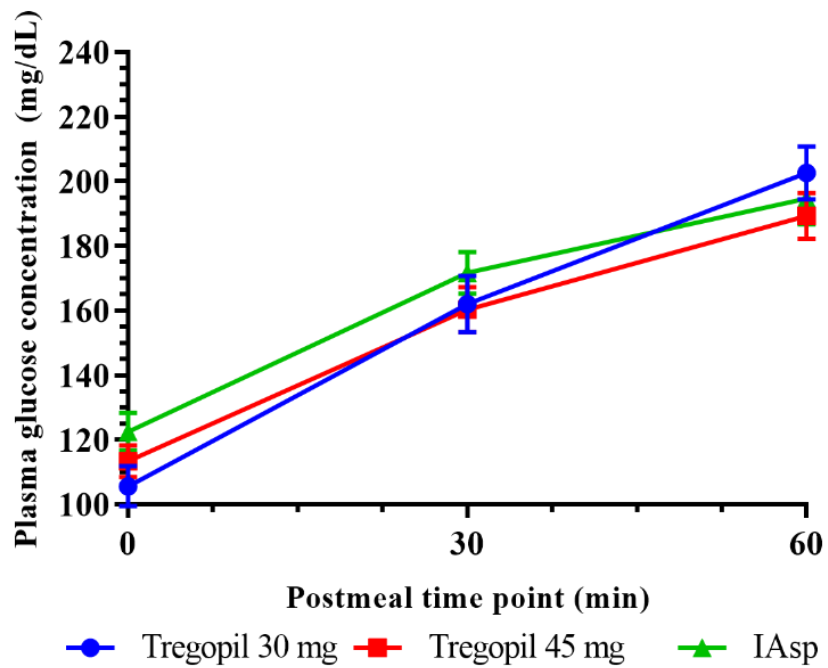

c) 24 weeks of treatment up to 1-h



\section{b) Pre-treatment up to $4-h$}

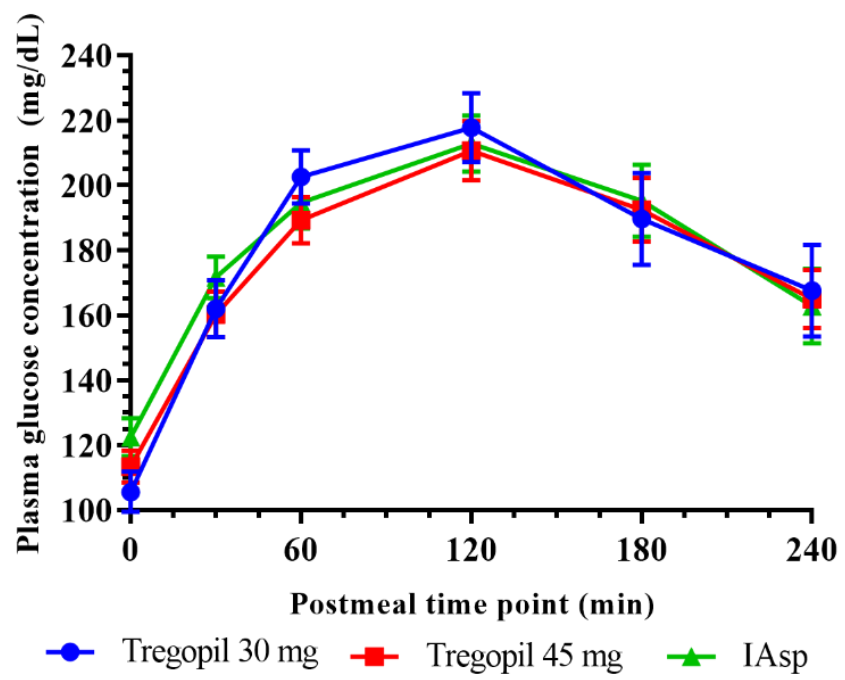

d) 24 weeks of treatment up to 4-h

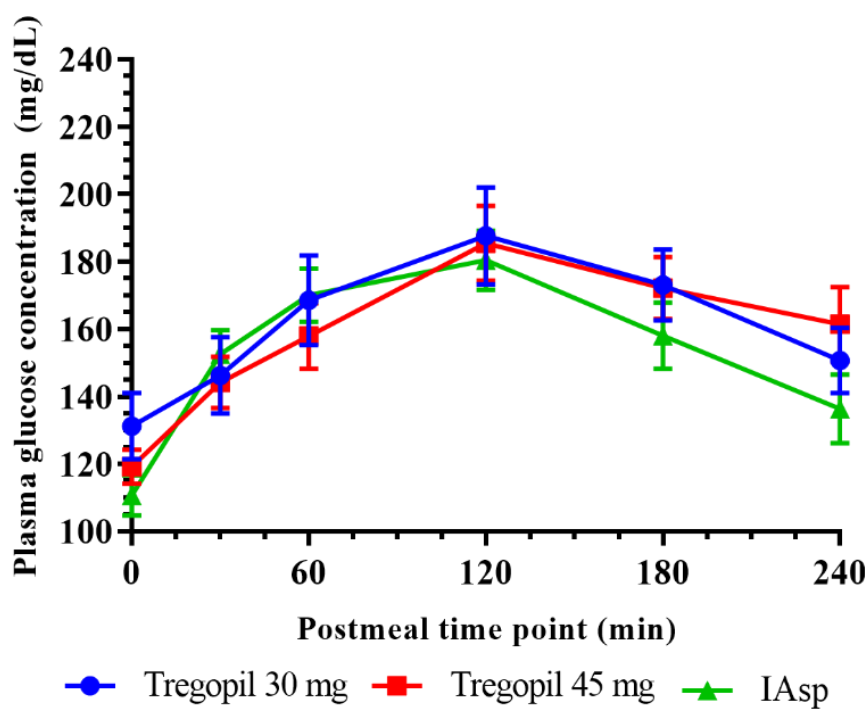


medRxiv preprint doi: https://doi.org/10.1101/2022.02.15.22270708; this version posted February 15, 2022. The copyright holder for this preprint (which was not certified by peer review) is the author/funder, who has granted medRxiv a license to display the preprint in

All rights reserved. No reuse allowed without permission.

Figure 1: STM - Mean plasma glucose concentration (PPG) vs time - a) at pre-treatment up to 1-h; b) at pre-treatment up to 4-h; c) at week 24 up to 1-h; d) at week 24 up to 4-h

Mean with SEM for PPG is presented in the above graphs. Post meal timepoint - 0 min indicates, 10 minutes after the dose, i.e., meal start time.

\section{PPGE}

At week 24, 1-h PPGE (mean and CFB) showed a trend towards more effective control in Tregopil groups compared to IAsp group (Table 1), with the Tregopil $30 \mathrm{mg}$ group (ETD) $[95 \% \mathrm{CI}],-45.33 \mathrm{mg} / \mathrm{dL}(-71.91,-18.75), P=0.001)$ and the combined Tregopil group $(30 \mathrm{mg}$ + $45 \mathrm{mg})(-33.91 \mathrm{mg} / \mathrm{dL}[-56.72,-11.09], P=0.004)$ showing a significant difference (Supplementary Table S2). The week 24 mean PPGE levels at 1.5-h and 2-h in Tregopil groups were controlled as effectively as in the IAsp group (Table 1). However, Tregopil groups displayed a trend towards better reduction of 1-h, 1.5-h, and 2-h PPGE from baseline compared to IAsp. At 3- and 4-h, the PPGE levels (mean and CFB) were similar in the combined Tregopil group and the IAsp group. At week 12, similar trends were observed except at 1.5-h, where IAsp showed better reduction than Tregopil (30 mg).

Additional analyses showed that Tregopil (combined dose group) was associated with lower PPGE at 15 min compared to IAsp; however, the difference was not statistically significant (week 24, $9.46 \mathrm{mg} / \mathrm{dL}$ vs. $21.46 \mathrm{mg} / \mathrm{dL} ; P=0.076$ ). The lower mean PPGE in Tregopil groups (combined) continued through 30- and 45- min post meal at week 24 for both combined Tregopil and IAsp groups (30 min, $20.65 \mathrm{mg} / \mathrm{dL}$ vs. $39.70 \mathrm{mg} / \mathrm{dL} ; P=0.022 ; 45 \mathrm{~min}, 29.00 \mathrm{mg} / \mathrm{dL}$ vs. $45.44 \mathrm{mg} / \mathrm{dL} ; P=0.109)$, thereby demonstrating the faster onset of action of Tregopil. Similar differences in the mean PPGE were observed at week 12 between combined Tregopil and IAsp groups $(30 \mathrm{~min}, 10.9 \mathrm{mg} / \mathrm{dL}$ vs. $33.0 \mathrm{mg} / \mathrm{dL} ; P=0.002 ; 45 \mathrm{~min}, 20.0 \mathrm{mg} / \mathrm{dL}$ vs. $40.8 \mathrm{mg} / \mathrm{dL}$; $P=0.023)$. 
medRxiv preprint doi: https://doi.org/10.1101/2022.02.15.22270708; this version posted February 15, 2022. The copyright holder for this preprint (which was not certified by peer review) is the author/funder, who has granted medRxiv a license to display the preprint in All rights reserved. No reuse allowed without permission.

Post meal glucose AUC (by STM) at week 24 was lower in the combined Tregopil group compared to the IAsp group at 1 -h $\left(\mathrm{AUC}_{0-1 \mathrm{~h}}, P=0.050\right)$ and, at week 12 , similar significant reductions in AUC were observed at 1-h and 2-h $\left(\mathrm{AUC}_{0-1 \mathrm{~h}}, P=0.004 ; \mathrm{AUC}_{0-2 \mathrm{~h}}, P=0.033\right)$. Also, $\mathrm{AUC}_{0-3 \mathrm{~h}}$ and $\mathrm{AUC}_{0-4 \mathrm{~h}}$ were similar between the treatment groups at week 24 (Table 2). 
medRxiv preprint doi: https://doi.org/10.1101/2022.02.15.22270708; this version posted February 15, 2022. The copyright holder for this preprint (which was not certified by peer review) is the author/funder, who has granted medRxiv a license to display the preprint in

All rights reserved. No reuse allowed without permission.

Table 1: Summary of postprandial plasma glucose (PPG) and postprandial plasma glucose excursions (PPGE) at different post mealtime points during STM at week 24

\begin{tabular}{|c|c|c|c|c|c|c|}
\hline & & & $\begin{array}{l}\text { Tregopil 30 mg } \\
\quad(N=30)\end{array}$ & $\begin{array}{l}\text { Tregopil } 45 \\
\text { mg } \\
(N=31)\end{array}$ & $\begin{array}{c}\text { IAsp } \\
(N=30)\end{array}$ & $\begin{array}{l}\text { Tregopil } 30 \mathrm{mg} \\
\quad+45 \mathrm{mg} \\
(N=61)\end{array}$ \\
\hline \multicolumn{7}{|c|}{ PPG (mg/dL) } \\
\hline \multirow[t]{13}{*}{ Week 24} & 0 min & Mean & $131.20(43.42)$ & $118.60(27.10)$ & $114.90(26.20)$ & - \\
\hline & & CFB & $27.00(37.76)$ & $9.80(41.01)$ & $-6.50(35.86)$ & - \\
\hline & 1-h & Mean & $168.50(69.34)$ & $157.90(52.88)$ & $170.10(41.74)$ & - \\
\hline & & CFB & $-34.40(67.52)$ & $-29.90(54.86)$ & $-25.00(50.76)$ & - \\
\hline & 1.5-h & Mean & $184.70(75.76)$ & $173.60(53.69)$ & $181.20(44.49)$ & - \\
\hline & & CFB & $-25.90(82.19)$ & $-27.40(58.54)$ & $-29.80(57.42)$ & - \\
\hline & 2-h & Mean & $187.70(74.54)$ & $185.50(60.85)$ & $180.40(45.98)$ & - \\
\hline & & CFB & $-29.30(94.67)$ & $-23.40(60.60)$ & $-34.20(60.79)$ & - \\
\hline & 3-h & Mean & $173.10(54.87)$ & $172.20(50.67)$ & $158.10(50.01)$ & - \\
\hline & & CFB & $-19.00(90.24)$ & $-20.30(56.20)$ & $-42.40(55.54)$ & - \\
\hline & 4-h & Mean & $150.70(50.29)$ & $161.40(61.04)$ & $136.30(52.06)$ & - \\
\hline & & CFB & $-20.20(84.25)$ & $-3.80(57.30)$ & $-32.20(49.78)$ & - \\
\hline & & & $\begin{array}{c}\text { Mean (SD) } \\
n=27\end{array}$ & $\begin{array}{c}\text { Mean (SD) } \\
n=\mathbf{3 0}^{\#} \\
\end{array}$ & $\begin{array}{c}\text { Mean (SD) } \\
n=27 *\end{array}$ & $\begin{array}{c}\text { Mean (SD) } \\
n=\mathbf{5 7}\end{array}$ \\
\hline \multicolumn{7}{|c|}{ PPGE (mg/dL) } \\
\hline \multirow[t]{10}{*}{ Week 24} & 1-h & Mean & $37.30(50.30)$ & $39.37(47.69)$ & $55.15(34.56)$ & $38.39(48.51)$ \\
\hline & & CFB & $-61.44(45.84)$ & $-39.73(55.97)$ & $-16.11(37.46)$ & $-50.02(52.13)$ \\
\hline & 1.5-h & Mean & $53.56(55.13)$ & $55.07(45.13)$ & $66.30(36.13)$ & 54.35 (49.66) \\
\hline & & CFB & $-52.89(59.93)$ & $-37.23(61.73)$ & $-21.63(37.88)$ & $-44.65(60.86)$ \\
\hline & 2-h & Mean & $56.56(54.41)$ & $66.90(53.27)$ & $65.52(34.58)$ & $62.00(53.58)$ \\
\hline & & CFB & $-56.30(77.51)$ & $-33.20(67.09)$ & $-26.07(42.50)$ & $-44.14(72.46)$ \\
\hline & 3-h & Mean & $41.89(43.30)$ & $53.60(54.57)$ & $43.42(41.79)$ & $48.05(49.47)$ \\
\hline & & CFB & $-46.07(78.74)$ & $-30.10(71.03)$ & $-37.27(43.91)$ & $-37.67(74.54)$ \\
\hline & 4-h & Mean & $19.56(39.49)$ & $42.87(56.46)$ & $21.62(45.15)$ & $31.82(50.13)$ \\
\hline & & CFB & $-47.22(72.64)$ & $-13.67(59.37)$ & $-28.50(44.39)$ & $-29.56(67.53)$ \\
\hline
\end{tabular}

$*_{n}=26$ for 3-h and 4-h actual PPGE and CFB in IAsp group; $n=26$ for 3-h and 4-h actual PPG in IAsp group; $n=25$ for 3-h and 4-h CFB in IAsp group.

Baseline was defined as the last observed value of a parameter before first intake of trial medication. Change from baseline (CFB) was calculated as the difference between value of interest and corresponding baseline value.

PPGE - Post prandial glucose excursion; STM - Standardized test meal; CFB - Change from baseline STM; SD Standard deviation; IAsp - Insulin Aspart. 
medRxiv preprint doi: https://doi.org/10.1101/2022.02.15.22270708; this version posted February 15, 2022. The copyright holder for this preprint (which was not certified by peer review) is the author/funder, who has granted medRxiv a license to display the preprint in

All rights reserved. No reuse allowed without permission.

Table 2: Mean differences and T/R ratio (\%) of AUC for Tregopil $30 \mathrm{mg}+45 \mathrm{mg}$ vs IAsp following a STM at week 24

\begin{tabular}{|c|c|c|c|c|c|}
\hline \multirow{2}{*}{$\begin{array}{c}\text { Timepoints at } \\
\text { week } 24\end{array}$} & \multicolumn{3}{|c|}{ LSMD [95\% CI] } & \multicolumn{2}{|c|}{ T/R ratio $(\%)$} \\
\hline & $\begin{array}{c}\text { Tregopil } 30 \\
\text { mg } \\
\text { vs } \\
\text { IAsp }\end{array}$ & $\begin{array}{c}\text { Tregopil } \\
45 \mathrm{mg} \\
\text { vs } \\
\text { IAsp }\end{array}$ & $\begin{array}{c}\text { Tregopil } \\
30 \mathrm{mg}+45 \mathrm{mg} \\
\text { vs } \\
\text { IAsp }\end{array}$ & $\begin{array}{c}\text { Tregopil } \\
30 \mathrm{mg} \\
\text { Vs } \\
\text { IAsp }\end{array}$ & $\begin{array}{c}\text { Tregopil } \\
45 \mathrm{mg} \\
\text { vs } \\
\text { IAsp }\end{array}$ \\
\hline $\begin{array}{c}\text { AUC } \\
(\mathbf{0 - 1 h})\end{array}$ & $\begin{array}{l}-1109 \\
{[-2148} \\
-68.75]\end{array}$ & $\begin{array}{l}-702.7 \\
{[-1743,} \\
337.15]\end{array}$ & $\begin{array}{c}-905.7 \\
{[-1812,1.12]}\end{array}$ & 96.47 & 95.95 \\
\hline$P$ value & 0.037 & 0.183 & 0.050 & & \\
\hline $\begin{array}{l}\text { AUC } \\
(0-2 h)\end{array}$ & $\begin{array}{l}-2070 \\
{[-4505,} \\
364.96]\end{array}$ & $\begin{array}{c}-1146 \\
{[-3581} \\
1289.3]\end{array}$ & $\begin{array}{c}-1608 \\
{[-3731,515.46]}\end{array}$ & 100.20 & 97.30 \\
\hline$P$ value & 0.095 & 0.353 & 0.136 & & \\
\hline $\begin{array}{c}\text { AUC } \\
(\mathbf{0 - 3 h})\end{array}$ & $\begin{array}{l}-2540 \\
{[-6356,} \\
1275.2]\end{array}$ & $\begin{array}{l}-628.4 \\
{[-4444,} \\
3187.1]\end{array}$ & $\begin{array}{c}-1526 \\
{[-4428,1376.6]}\end{array}$ & - & - \\
\hline$P$ value & 0.190 & 0.745 & 0.348 & & \\
\hline $\begin{array}{l}\text { AUC } \\
(0-4 h)\end{array}$ & $\begin{array}{c}-2487 \\
{[-7519,} \\
2544.7]\end{array}$ & $\begin{array}{l}473.77 \\
{[-4558} \\
5505.4]\end{array}$ & $\begin{array}{c}-1007 \\
{[-5394,3381.1]}\end{array}$ & 104.29 & 103.20 \\
\hline$P$ value & 0.330 & 0.852 & 0.650 & & \\
\hline
\end{tabular}

IAsp- Insulin Aspart, AUC - Area under curve; STM - Standardized test meal; LSMD - Least squared mean difference; $95 \%$ CI - 95\% confidence interval

\section{9-Point Self-Monitoring Blood Glucose}

\section{$P P G$}

At week 24, mean PPG levels were comparable between the Tregopil and IAsp groups at 1 and $2 \mathrm{~h}$ post breakfast and $1 \mathrm{~h}$ post lunch (Supplementary Table S3). PPG levels were significantly higher in the Tregopil groups than in the IAsp group at $2 \mathrm{~h}$ post lunch and 1 and $2 \mathrm{~h}$ post dinner. However, the CFB in mean PPG at different post meal timepoints (Supplementary Fig. S4) 
medRxiv preprint doi: https://doi.org/10.1101/2022.02.15.22270708; this version posted February 15, 2022. The copyright holder for this preprint (which was not certified by peer review) is the author/funder, who has granted medRxiv a license to display the preprint in

All rights reserved. No reuse allowed without permission.

were comparable between treatment groups except for the $2 \mathrm{~h}$ post dinner value favoring IAsp versus both the Tregopil groups, $30 \mathrm{mg}(P=0.020)$ and $45 \mathrm{mg}(P=0.047)$ (Supplementary Table S4).

The proportion of patients who achieved 2-h PPG $<140 \mathrm{mg} / \mathrm{dL}$ at week 24 (from SMBG) was numerically higher in the Tregopil groups (30 $\mathrm{mg}, 25.0 \%: 45 \mathrm{mg}, 23.3 \%$ ) than the IAsp group (17.2\%). Similarly, the proportion of patients who achieved 2-h PPG $<140 \mathrm{mg} / \mathrm{dL}$ following STM was numerically higher in the Tregopil groups (30 mg, 21.4\%; $45 \mathrm{mg}, 26.7 \%$ ) compared to the IAsp group (17.2\%) (Supplementary Fig. S3). At the end of the titration period, despite the highest allowable dose (45 mg TID) in the study, the Tregopil $45 \mathrm{mg}$ group had $>60 \%$ of patients (with 2-h PPG by SMBG >180 mg/dL) indicating the need for a higher dose.

\section{PPGE}

Overall, at week 24, the 1-h and 2-h PPGE (mean and CFB) at breakfast, lunch, and dinner did not show statistically significant differences between the treatment groups. The CFB in all 1-h post meal PPGE and 2-h post breakfast excursion showed a trend towards more effective control in the Tregopil groups than IAsp (Fig. 2 a, b, and c). PPGE was numerically lower in the Tregopil groups at 2-h post breakfast, but CFB was better for IAsp. The mean 1- and 2-h PPGE at week 24 is represented in Supplementary Table S3. 
medRxiv preprint doi: https://doi.org/10.1101/2022.02.15.22270708; this version posted February 15, 2022. The copyright holder for this preprint (which was not certified by peer review) is the author/funder, who has granted medRxiv a license to display the preprint in All rights reserved. No reuse allowed without permission.

a) PPGE (by SMBG) - Breakfast

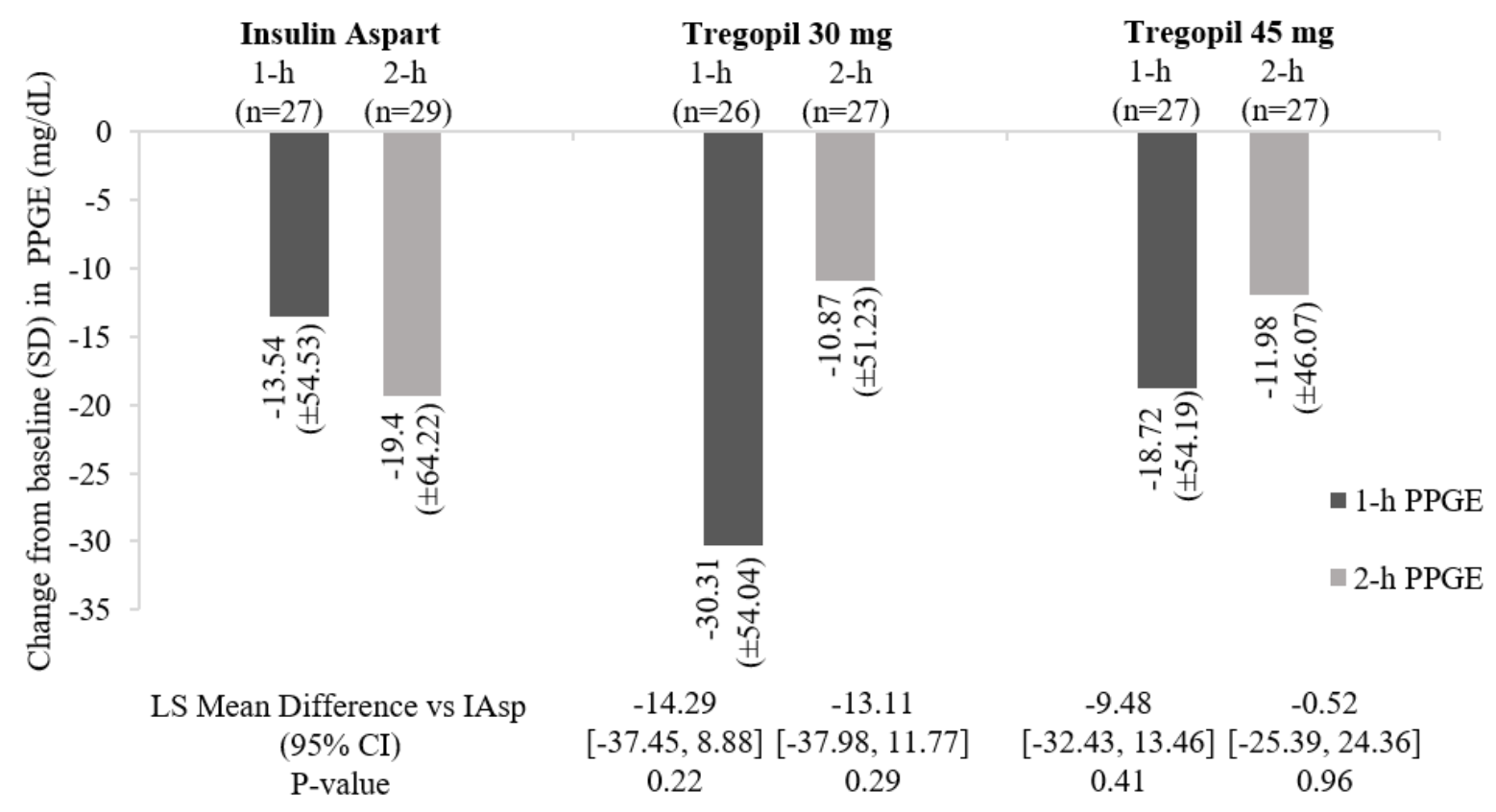

b) PPGE (by SMBG) - Lunch

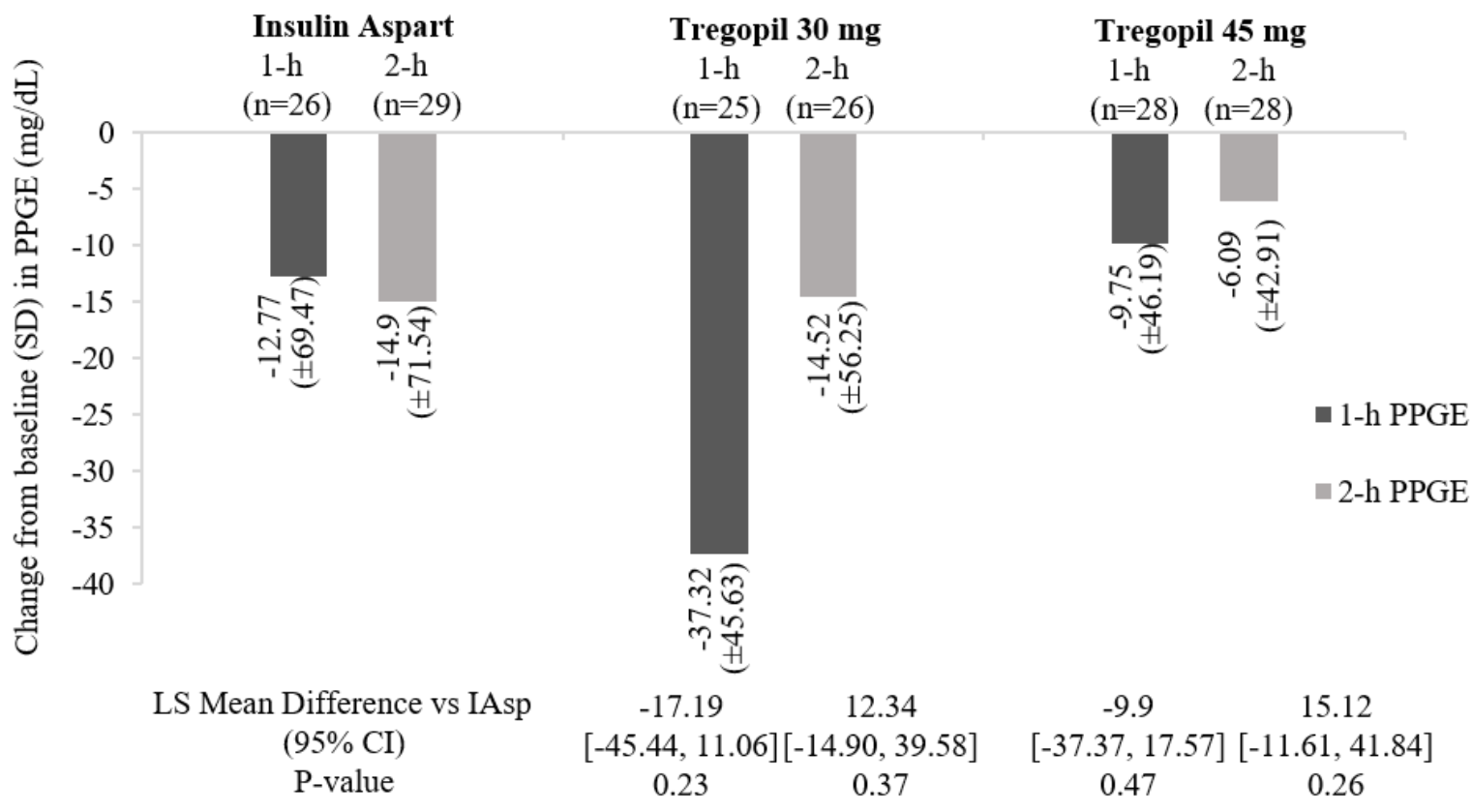


medRxiv preprint doi: https://doi.org/10.1101/2022.02.15.22270708; this version posted February 15, 2022. The copyright holder for this preprint (which was not certified by peer review) is the author/funder, who has granted medRxiv a license to display the preprint in All rights reserved. No reuse allowed without permission.

c) PPGE (by SMBG) - Dinner



Figure. 2: CFB in PPGE levels ( 1 and $2 \mathrm{~h}$ ) from 9-point SMBG at week 24 following each meal of the day. a) CFB in PPGE by SMBG at breakfast; b) CFB in PPGE by SMBG at lunch; c) CFB in PPGE by SMBG at dinner.

Baseline was defined as the last observed value of a parameter before first intake of trial medication. Change from baseline (CFB) was calculated as the difference between value of interest and corresponding baseline value.

\section{HbA1c}

The mean CFB in measured $\mathrm{HbA}_{1 \mathrm{c}}$ at weeks 24 and 12 for the Tregopil groups was $0.15 \%$ and $-0.07 \%$ for $30 \mathrm{mg}$ and $0.22 \%$ and $-0.17 \%$ for $45 \mathrm{mg}$, respectively. For the IAsp group, the mean CFB for measured $\mathrm{HbA}_{1 \mathrm{c}}$ at weeks 24 and 12 were $-0.77 \%$ and $-0.88 \%$, respectively.

The $\mathrm{HbA}_{1 \mathrm{c}}$ analysis, interestingly revealed a discordance in the mean glucose-HbA1c in the Tregopil groups but not in the IAsp group. To further explore this finding, the measured $\mathrm{HbA}_{1 \mathrm{c}}$ was compared to estimated $\mathrm{A} 1 \mathrm{c}\left(\mathrm{eA}_{1 \mathrm{c}}\right)$ calculated from the mean overall daily blood glucose measurements based on 9-point SMBG using previously published methodologies (17). The 
medRxiv preprint doi: https://doi.org/10.1101/2022.02.15.22270708; this version posted February 15, 2022. The copyright holder for this preprint (which was not certified by peer review) is the author/funder, who has granted medRxiv a license to display the preprint in

All rights reserved. No reuse allowed without permission.

results showed a reduction from baseline in eA1c at week 24 in the insulin Tregopil groups as opposed to the slight increase seen with the central laboratory measured HbA1c. However, this discrepancy between eA1c and measured A1c was not observed in the IAsp group (Supplementary Table S5).

\section{Changes in Fasting Plasma Glucose and Body Weight}

FPG increased from baseline in Tregopil groups but not in the IAsp group. At week 24, the mean FPG increased from $107.2 \pm 31.0$ to $132 \pm 5 \mathrm{mg} / \mathrm{dL}(\mathrm{CFB}:+24.1 \mathrm{mg} / \mathrm{dL})$ in the Tregopil $30 \mathrm{mg}$ group and from $109.7 \pm 27.3$ to $120 \pm 27 \mathrm{mg} / \mathrm{dL}(\mathrm{CFB}:+11.8 \mathrm{mg} / \mathrm{dL})$ in Tregopil $45 \mathrm{mg}$ group, while the FPG decreased from $120.5 \pm 32.2$ to $113 \pm 29 \mathrm{mg} / \mathrm{dL}$ (CFB:- $9.6 \mathrm{mg} / \mathrm{dL}$ ) with IAsp.

\section{Effect on body weight}

There was no significant change in mean body weight in any of the treatment groups during the treatment period in this study.

\section{Safety}

\section{Adverse events}

Overall, Tregopil was safe and well tolerated. The proportion of patients with at least one TEAE in the Tregopil groups (30 and $45 \mathrm{mg}$ ) were $20.0 \%$ and $16.1 \%$ respectively and with IAsp, $13.3 \%$ (Supplementary Table S6). Of the total population, $16.5 \%$ patients reported overall 29 TEAEs. Majority of the TEAEs (21 of 29; most common: pyrexia and gastritis) were mild in intensity (Tregopil $30 \mathrm{mg}[n=4] 4$ events; Tregopil $45 \mathrm{mg}$ [ $n=4] 10$ events; IAsp [ $n=4] 7$ events). Seven moderate-intensity TEAEs were reported (Tregopil $30 \mathrm{mg}[n=2] 3$ events, Tregopil $45 \mathrm{mg}[n=1] 4$ events). No severe TEAEs or SAEs were reported in the study. 
medRxiv preprint doi: https://doi.org/10.1101/2022.02.15.22270708; this version posted February 15, 2022. The copyright holder for this preprint (which was not certified by peer review) is the author/funder, who has granted medRxiv a license to display the preprint in

All rights reserved. No reuse allowed without permission.

\section{Hypoglycemia}

The percentage of patients who reported any hypoglycemic events across Tregopil groups (30 and $45 \mathrm{mg}$ ) were $86.7 \%$ and $83.9 \%$, respectively, and $83.3 \%$ with IAsp. The rate (events/per 100 years of exposure) of clinically significant (level 2: ADA Hypoglycemic Episode Level 2 Definition: Glycemic level $<54 \mathrm{mg} / \mathrm{dL}$; Sufficiently low to indicate serious, clinically important hypoglycemia) treatment-emergent hypoglycemia events in the Tregopil groups (30 mg, 282.9; $45 \mathrm{mg}, 193.3$ ) were lower compared to the IAsp group (346.3) (combined Tregopil groups vs. IAsp, rate ratio [RR]: 0.69). The incidence of hypoglycemic events during each post meal period was lower in the Tregopil groups than with IAsp (Supplementary Table S6).

\section{CONCLUSIONS}

Tregopil is an ultrafast, short-acting, oral prandial insulin with a peak action at around 30-40 min and a duration of action of 2-3 h. Tregopil resulted in an improved control of PPH over a 4-h post-meal period in patients with type 2 diabetes when administered 10 min before major meals, in addition to optimized and stable basal insulin and other medications.

In this study, Tregopil at a $45 \mathrm{mg}$ daily dose resulted in an average 1-h PPG level of $157.9 \mathrm{mg} / \mathrm{dL}$, which was close to the required 1-h cut-off value of $155 \mathrm{mg} / \mathrm{dL}$ (18). Uncontrolled PPG is considered an important predictor of developing diabetes and is linked to inflammation, thrombosis, endothelial dysfunction, and oxidative stress generation, all of which may contribute to the pathogenesis of cardiovascular disease $(19,20)$.

The STM assessment (at breakfast) showed that the oral Tregopil reduced 1-h and 2-h PPG levels and excursions as effectively or, in some instances (early post meal period), more effectively than premeal IAsp. As expected, Tregopil's effect on 3-h and 4-h PPG reduction 
medRxiv preprint doi: https://doi.org/10.1101/2022.02.15.22270708; this version posted February 15, 2022. The copyright holder for this preprint (which was not certified by peer review) is the author/funder, who has granted medRxiv a license to display the preprint in All rights reserved. No reuse allowed without permission.

was less than IAsp. However, cumulative glucose control over the 4-h post meal period (AUC) was comparable between Tregopil and IAsp.

Similarly, results of the 9-point SMBG studies at baseline and at 12 and 24 weeks of treatment showed Tregopil to be (1) as effective or more effective compared to IAsp in reducing PPG levels and excursions 1-h and 2-h after breakfast; (2) as effective in lowering 1-h PPG and excursions at lunch but (3) trending towards less effective control of 2-h PPG after lunch and 1-h and 2-h PPG after dinner. The effect of Tregopil was greatest during breakfast, lower at lunch, and least during the evening meal. The study's most significant finding is that Tregopil works particularly well at breakfast, a meal with a high physiological requirement of insulin. Higher Tregopil doses or the addition of supplementary basal insulin to regulate basal glucose levels (i.e., fasting and between-meals) can compensate for the suboptimal control during later meals of the day, resulting in better glycemic control in patients with type 2 diabetes on the Tregopil regimen.

The results indicate that Tregopil could provide a glycemic control comparable to IAsp in patients with type 2 diabetes who have significantly elevated PPG despite near-normal FPG ( $<120 \mathrm{mg} / \mathrm{dL}$ based on SMBG). A post-hoc responder analysis for different \% cut offs of HbA1c at week 24 showed: 1) A clinically relevant $0.3 \%$ reduction in HbA1c from baseline in $40 \%$ patients in the Tregopil $30 \mathrm{mg}$ group and $45.1 \%$ in $45 \mathrm{mg}$ group versus $66.6 \%$ in the IAsp group. 2) Any reduction in HbA1c in nearly $50 \%$ of patients in the Tregopil $30 \mathrm{mg}$ group, $45.6 \%$ in $45 \mathrm{mg}$ group and $86.7 \%$ in IAsp group. A further subgroup analysis demonstrated that decrease in the measured $\mathrm{HbA}_{1 \mathrm{c}}$ from baseline was greatest in patients with well-controlled FPGs, emphasizing the importance of FPG in reflecting the effect of PPG control on $\mathrm{HbA}_{1 \mathrm{c}}$ reduction (14). This is especially true with Tregopil, which, unlike IAsp, has a shorter duration of glucose-lowering activity. Tregopil's shorter time action profile also explains the modest increase in FPG associated with Tregopil but not with IAsp therapy throughout the 24-week 
medRxiv preprint doi: https://doi.org/10.1101/2022.02.15.22270708; this version posted February 15, 2022. The copyright holder for this preprint (which was not certified by peer review) is the author/funder, who has granted medRxiv a license to display the preprint in

All rights reserved. No reuse allowed without permission.

treatment. The effect of IAsp begins 15 minutes after the injection and lasts for 4-6 hours. IAsp, due to its longer duration of action, reduces inter-meal glucose levels to some extent, lessening the need for basal insulin, while also predisposing the patient to late-phase hypoglycemia. Adding Tregopil to a regimen of basal insulin and OADs with continued FPG optimization may result in a better overall glycemic control and not just PPG improvement as observed in this study. Oral insulin Tregopil can be especially useful in type 2 diabetes patients on basal+, basal++ or bolus regimens in subgroup of patients with good FPG control to further improve overall glycemic control.

Tregopil may be potentially beneficial in special settings such as when patients need insulin for PPG control during travel or other short-term situations where use of injectable formulations is inconvenient.

It is well known that $\mathrm{HbA}_{1 c}$ measurements can be influenced by factors (21) other than glucose levels, such as hemoglobinopathies, red blood cell (RBC) survival (22), and metabolic factors influencing the glycation reaction. Information about glycemic variability or differentiation among fasting, pre-prandial and post-prandial glycemia is not accurately reflected by $\mathrm{HbA}_{1 \mathrm{c}}$ (23). It is not surprising, therefore, that $\mathrm{HbA}_{1 \mathrm{c}}$ may not accurately represent the improvement in overall daily mean blood glucose levels, especially PPH reduction in Tregopil-treated patients. In IAsp-treated patients, the improvement in glucose control was reflected by an appropriate reduction in $\mathrm{HbA}_{1 \mathrm{c}}$ measurement. This difference indicates that $\mathrm{HbA}_{1 \mathrm{c}}$ may not be a complete measure of glycemic control in patients treated with Tregopil. Our observations that plasma glucose variations over time may not be fully reflected in $\mathrm{HbA}_{1 \mathrm{c}}$ measurements underscores the need of exploring alternative glycemic markers.

Oral insulin absorbed from the gastrointestinal tract with an ultrafast onset-of-action could effectively target excessive and prolonged PPG excursions and can limit insulin exposure to 
medRxiv preprint doi: https://doi.org/10.1101/2022.02.15.22270708; this version posted February 15, 2022. The copyright holder for this preprint (which was not certified by peer review) is the author/funder, who has granted medRxiv a license to display the preprint in All rights reserved. No reuse allowed without permission.

peripheral tissues, thereby reducing hypoglycemia risk and weight gain. The duration and size of this study limited the evaluation of Tregopil's effect on body weight. However, it shows a potential towards a lower risk of hypoglycemia associated with Tregopil treatment than an injected prandial insulin.

Strengths of the present study include a run-in period resulting in optimized basal insulin and antidiabetic medications and a more homogeneous population at randomization; an activecontrolled study with prandial IAsp with appropriate titration; stable maintenance period to evaluate sustenance of use; and application of both standardized meal test and real-life scenario for evaluation (SMBG) of PPG control. This was a well-monitored study with standard of care counseling, including lifestyle modifications. A titration review committee monitored the dose titrations throughout the study.

The major limitation of the study is its open-label design due to difference in routes of administration of the test and control drugs and the ethical challenges of the double-dummy design due to the daily administration of three SC injections of active control drug. The requirement of up-titration allowed up to a maximum of 8 weeks to achieve desired glycemic control was high, as $\sim 90 \%$ of patients in the Tregopil $30 \mathrm{mg}$ group were up-titrated to $45 \mathrm{mg}$ for at least one of the doses daily. Additionally, the small size of the study population limited the statistical power and interpretation of results.

In conclusion, this study demonstrates the efficacy of oral Tregopil in controlling PPG excursions with a lower incidence of clinically significant hypoglycemia compared to IAsp in patients with type 2 diabetes on a basal-bolus regimen. Tregopil had a more rapid onset and a shorter duration of action than IAsp. Tregopil is effective at controlling PPG excursions; however, further modifications in basal insulin dosage may be required for good FPG management. These features, along with early PPH control and low hypoglycemia risk, make 
medRxiv preprint doi: https://doi.org/10.1101/2022.02.15.22270708; this version posted February 15, 2022. The copyright holder for this preprint (which was not certified by peer review) is the author/funder, who has granted medRxiv a license to display the preprint in

All rights reserved. No reuse allowed without permission.

oral Tregopil a potentially attractive treatment option for type 2 diabetes, especially in patients with a good FPG control.

Acknowledgments. The authors thank all investigators and study participants for generously contributing their time for this study. The authors acknowledge support by Hema Balasubramanian (Biocon Biologics Ltd) and Vasan Sambandamurthy and Nikhil Dixit (exemployees of Biocon) for their contribution towards clinical operation activities related to this study. The authors extend their thanks to Vathsala Jayanth, MD (Biocon Biologics Ltd) for medical writing support under their guidance. The authors acknowledge Molecular Connection Pvt. Ltd., Bengaluru, India for editorial services towards development of this article.

Funding. The study was funded by Biocon Limited, India.

Duality of interest. H.E.L. is a scientific advisor for Biocon, Intarcia Pharmaceuticals, Metacure Ltd., and Poxel Pharmaceuticals and holds stocks in Abbott, AbbVie, Inc., General Electric, Gilead Sciences, Inc., IBM, Nestlé, and Novartis AG. A.F. is a board member of Tolerion and Innoneo and a consultant at Acasti, Adocia, Biocon, Cardiora, Carthera, Casebia, Diamyd, Diasome, Dance, EnteraBio, Emperra, Fractyl, G-Medical, Immune Pharma, InsuLine Medical, Intarcia Therapeutics, Intra-Cellular Therapeutics, InClinica, Ipsen Biopharmaceuticals, Lexicon, Mars Symbioscience, Mediwound, Merck KGaA, Mediwound, Metronom, Mylan, Neovii, NuSirt Biopharma, Orgenesis, Oramed, Permeatus, ProSciento, RenovoRx, Rhythm Pharmaceuticals, Sanofi, Serpin, SkinJect, Suzhou Connect, Thermalin, ThermoFisher, Upkara, Veracyte, VeroScience, Xeris Pharmaceuticals, and Zucara. A.D.C. is a scientific advisor for Biocon, Fractyl Laboratories, Inc., Metavention, Sensulin Labs, LLC., vTV Therapeutics, and also a consultant at Abvance, Novo Nordisk Inc., Thetis Pharmaceutica LLC., and vTV Therapeutics and reports research support from Novo Nordisk, Inc., Senda Biosciences Inc., Cellular Longevity, Inc., dba Loyal, and holds stocks in Fractyl Laboratories, 
medRxiv preprint doi: https://doi.org/10.1101/2022.02.15.22270708; this version posted February 15, 2022. The copyright holder for this preprint (which was not certified by peer review) is the author/funder, who has granted medRxiv a license to display the preprint in All rights reserved. No reuse allowed without permission.

Inc., Metavention, Thetis Pharmaceuticals LLC., and Zafgen. S.R.J. has received Speaker/Advisory/Research Grants from Abbott, Astra, Biocon, Boehringer Ingelheim, Eli Lilly, Franco Indian, Glenmark, Lupin, Marico, MSD, Novartis, Novo Nordisk, Roche, Sanofi, Serdia and Zydus. S.N.A., S.L, J.P and A.M hold shares of Biocon Biologics Ltd. A.V is an ex-employee of Biocon.

Author Contributions. H.E.L., A.F., A.D.C., S.N.A., A.V., S.L., and S.R.J were involved in study conceptualization and design. A.M. was involved in data curation and data validation. J.P. was involved in project administration. All authors analyzed and interpreted the study data and results. All authors participated in the preparation and review of the manuscript. All authors read and approved the final version of the manuscript. 
medRxiv preprint doi: https://doi.org/10.1101/2022.02.15.22270708; this version posted February 15, 2022. The copyright holder for this preprint (which was not certified by peer review) is the author/funder, who has granted medRxiv a license to display the preprint in

All rights reserved. No reuse allowed without permission.

\section{REFERENCES}

1. Chamberlain JJ, Rhinehart AS, Shaefer CF, Neuman A. Diagnosis and Management of Diabetes: Synopsis of the 2016 American Diabetes Association Standards of Medical Care in Diabetes. Ann Intern Med. 2016 Apr 19;164(8):542.

2. Shah RB, Patel M, Maahs DM, Shah VN. Insulin delivery methods: Past, present and future. Int J Pharm Investig. 2016;6(1):1-9.

3. Shah VN, Moser EG, Blau A, Dhingra M, Garg SK. The future of basal insulin. Diabetes Technol Ther. 2013 Sep;15(9):727-32.

4. Russell-Jones D, Khan R. Insulin-associated weight gain in diabetes - causes, effects and coping strategies. Diabetes Obes Metab. 2007 Nov;9(6):799-812.

5. Fonte P, Araújo F, Reis S, Sarmento B. Oral Insulin Delivery: How Far Are We? J Diabetes Sci Technol. 2013 Mar 1;7(2):520-31.

6. Arbit E, Kidron M. Oral Insulin Delivery in a Physiologic Context: Review. J Diabetes Sci Technol. 2017 Feb 2;11(4):825-32.

7. Guimaraes C. Exploring patients\&rsquo; perceptions for insulin therapy in type 2 diabetes: a Brazilian and Canadian qualitative study. Patient Prefer Adherence. 2010 Jun;171.

8. Postprandial Blood Glucose | Diabetes Care. [cited 2021 Apr 9]; Available from: https://care.diabetesjournals.org/content/24/4/775.short

9. Erlinger TP, Brancati FL. Postchallenge Hyperglycemia in a National Sample of U.S. Adults With Type 2 Diabetes. Diabetes Care. 2001 Oct 1;24(10):1734-8.

10. Raccah D, Bretzel RG, Owens D, Riddle M. When basal insulin therapy in type 2 diabetes mellitus is not enough--what next? Diabetes Metab Res Rev. 2007 May;23(4):257-64.

11. Heinemann L, Muchmore DB. Ultrafast-acting insulins: state of the art. J Diabetes Sci Technol. 2012 Jul 1;6(4):728-42.

12. Home PD. Plasma insulin profiles after subcutaneous injection: how close can we get to physiology in people with diabetes? Diabetes Obes Metab. 2015 Nov;17(11):1011-20.

13. Sanlioglu AD, Altunbas HA, Balci MK, Griffith TS, Sanlioglu S. Clinical utility of insulin and insulin analogs. Islets. 2013 Mar 1;5(2):67-78.

14. Khedkar A, Iyer H, Anand A, Verma M, Krishnamurthy S, Savale S, et al. A dose range finding study of novel oral insulin (IN-105) under fed conditions in type 2 diabetes mellitus subjects. Diabetes Obes Metab. 2010 Aug;12(8):659-64.

15. American Diabetic Association. Standard of medical care in diabetes. 2017;40(Supplement 1). 
medRxiv preprint doi: https://doi.org/10.1101/2022.02.15.22270708; this version posted February 15, 2022. The copyright holder for this

preprint (which was not certified by peer review) is the author/funder, who has granted medRxiv a license to display the preprint in

All rights reserved. No reuse allowed without permission.

16. Nilsson ME, Koke SC. Defining Treatment-Emergent Adverse Events with the Medical Dictionary for Regulatory Activities (MedDRA). Drug Inf J. 2001 Oct 1;35(4):1289-99.

17. Nathan DM, Kuenen J, Borg R, Zheng H, Schoenfeld D, Heine RJ. Translating the A1C Assay Into Estimated Average Glucose Values. Diabetes Care. 2008 Aug 1;31(8):14738 .

18. Abdul-Ghani MA, Williams K, DeFronzo RA, Stern M. What Is the Best Predictor of Future Type 2 Diabetes? Diabetes Care [Internet]. 2007 Jun 1 [cited 2021 Nov 15];30(6):1544-8. Available from: https://care.diabetesjournals.org/content/30/6/1544

19. Cavalot F, Pagliarino A, Valle M, Martino LD, Bonomo K, Massucco P, et al. Postprandial Blood Glucose Predicts Cardiovascular Events and All-Cause Mortality in Type 2 Diabetes in a 14-Year Follow-Up: Lessons from the San Luigi Gonzaga Diabetes Study. Diabetes Care [Internet]. 2011 Oct 1 [cited 2021 Nov 15];34(10):223743. Available from: https://care.diabetesjournals.org/content/34/10/2237

20. Jiang J, Zhao L, Lin L, Gui M, Aleteng Q, Wu B, et al. Postprandial Blood Glucose Outweighs Fasting Blood Glucose and HbA1c in screening Coronary Heart Disease. Sci Rep [Internet]. 2017 Oct 27 [cited 2021 Nov 15];7(1):14212. Available from: https://www.nature.com/articles/s41598-017-14152-y

21. Nitin S. HbA1c and factors other than diabetes mellitus affecting it. Singapore Med J. 2010 Aug;51(8):616-22.

22. Rashed ER, Rashed ER. The Effects of Red Blood Cells Parameters on HbA1c and Random Blood Sugar Levels in Diabetics Diagnosis. [cited 2022 Feb 9]; Available from: https://clinmedjournals.org/articles/ijdcr/international-journal-of-diabetes-andclinical-research-ijdcr-7-128.php?jid=ijdcr

23. Lu J, Wang C, Cai J, Shen Y, Chen L, Zhang L, et al. Association of HbA1c With Allcause Mortality Across Varying Degrees of Glycemic Variability in Type 2 Diabetes. J Clin Endocrinol Metab [Internet]. 2021 Jul 19; Available from: http://dx.doi.org/10.1210/clinem/dgab532 